\title{
Seasonal Behavior of Mercury Species in Waters and Sediments from the Negro River Basin, Amazon, Brazil
}

\author{
Márcia Cristina Bisinoti, ${ }^{*, a}$ Ézio Sargentini Júnior ${ }^{b}$ and Wilson F. Jardim ${ }^{c}$ \\ ${ }^{a}$ Instituto de Biociências, Letras e Ciências Exatas, Departamento de Química e Ciências Ambientais, \\ Universidade Estadual Paulista, Rua Cristóvão Colombo, 2265, 15054-000 São José do Rio Preto-SP, Brazil \\ ${ }^{b}$ Coordenação de Pesquisas em Produtos Naturais, Química Analítica Ambiental, Instituto Nacional \\ de Pesquisas da Amazônia, C.P. 478, 69083-000 Manaus-AM, Brazil \\ 'Instituto de Química, Departamento de Química Analítica, Universidade Estadual de Campinas, \\ C.P. 6154, 13084-971 Campinas-SP, Brazil
}

\begin{abstract}
Espécies de mercúrio total $\left(\mathrm{Hg}_{\mathrm{T}}\right)$, reativo $\left(\mathrm{Hg}_{\mathrm{R}}\right)$ e orgânico $\left(\mathrm{Hg}_{\mathrm{ORG}}\right)$ foram quantificadas em amostras de água não filtradas da Bacia do Rio Negro, Amazonia (de Janeiro/2002 a Janeiro/ 2004) em ambos corpos aquáticos de águas brancas e pretas. As águas pretas apresentaram as maiores concentrações de mercúrio total, orgânico e reativo $\left(29,1 ; 1,63\right.$ e 3,9 ng L - $^{-1}$, respectivamente), sendo que as águas brancas apresentaram as menores concentrações de $\mathrm{Hg}_{\mathrm{T}}$, $\mathrm{Hg}_{\text {ORG }}$ e $\mathrm{Hg}_{\mathrm{R}}\left(8,8 ; 0,49\right.$ e 1,2 $\mathrm{ng} \mathrm{L}^{-1}$, respectivamente). Uma correlação inversa entre $\mathrm{Hg}_{\mathrm{T}}$ e o nível da água sobre a bacia foi obtido, embora a concentração de $\mathrm{Hg}_{\mathrm{ORG}}$ tenha aumentado nos primeiros meses chuvosos decrescendo com o aumento do nível da água. A concentração de $\mathrm{Hg}_{\mathrm{T}}$ em sedimentos superficiais $(0-10 \mathrm{~cm})$ variou de 70 a $271 \mathrm{mg} \mathrm{kg}^{-1}$, com o metilmercúrio sendo $0,47-1,79 \%$ deste estoque. Os resultados indicaram que $\mathrm{Hg}_{\mathrm{R}}$ e a matéria orgânica dissolvida e lábil estão sendo introduzidos no ambiente aquático durante a estação chuvosa, especialmente nos estágios iniciais contribuindo para a metilação de mercúrio.
\end{abstract}

Total $\left(\mathrm{Hg}_{\mathrm{T}}\right)$, reactive $\left(\mathrm{Hg}_{\mathrm{R}}\right)$ and organic $\left(\mathrm{Hg}_{\mathrm{ORG}}\right)$ mercury species have been quantified in non-filtered waters collected from the Negro River Basin, Amazon (from January/2002 through January/2004), in both black and white water bodies. Black waters presented the highest $\mathrm{Hg}_{\mathrm{T}}$, $\mathrm{Hg}_{\mathrm{ORG}}$ and $\mathrm{Hg}_{\mathrm{R}}$ concentration (29.1 $\mathrm{ng} \mathrm{L}^{-1}, 1.63 \mathrm{ng} \mathrm{L}^{-1}$ and $3.9 \mathrm{ng} \mathrm{L}^{-1}$, respectively), while, white waters presented the lowest $\mathrm{Hg}_{\mathrm{T}}, \mathrm{Hg}_{\mathrm{ORG}}$ and $\mathrm{Hg}_{\mathrm{R}}$ concentration $\left(8.8 \mathrm{ng} \mathrm{L}^{-1}, 0.49 \mathrm{ng} \mathrm{L}^{-1}\right.$ and 1.2 $n g \mathrm{~L}^{-1}$, respectively). An inverse correlation between $\mathrm{Hg}_{\mathrm{T}}$ and the water level over the basin was obtained, although the $\mathrm{Hg}_{\mathrm{ORG}}$ concentration has increased in the first rainy months and then decreased as the water level rose. Total mercury in surface sediments $(0-10 \mathrm{~cm})$ ranged from 70 to $271 \mathrm{mg} \mathrm{kg}^{-1}$ being the methylmercury $0.47-1.79 \%$ of this stock. The results indicate that $\mathrm{Hg}_{\mathrm{R}}$ and the labile dissolved organic matter were introduced into the aquatic environment during the flooding season, especially in the earlier stages, thus contributing to mercury methylation.

Keywords: organic mercury, mercury speciation, Negro River Basin, black and white waters

\section{Introduction}

The Negro River, situated in the northwest part of Brazil, covers an extension of approximately $1700 \mathrm{~km}$ and its basin spreads over an area of $696,800 \mathrm{~km}^{2}$, which represents $14 \%$ of the total area of the Brazilian Amazon region. ${ }^{1}$ According to Sioli, ${ }^{2,3}$ Amazon tributaries are generally classified according to their collor: black water, white water and intermediate water rivers. Black water

*e-mail: bisinoti@ibilce.unesp.br rivers, such as the Negro River, drain highly weathered sandy soils of the central Amazon basin, which show low sediment and nutrient concentrations, brown-colored acid waters rich in dissolved humic substances and acidic $\mathrm{pH}$. White waters, such as, Branco, Solimões and Madeira Rivers originate in the Andes and are characterized by a high suspended sediment load, neutral to slightly acidic $\mathrm{pH}$, low organic matter concentration (bellow $9 \mathrm{mg} \mathrm{C} \mathrm{L}^{-1}$ ) and rich in dissolved nutrients due to rapid weathering in piedmont regions. Intermediate water bodies present characteristics between black and white waters. 
Moreover, the Negro River basin is characterized by a diversified type of soil, vegetation, deforested areas and mainly by the hydrological cycle, showing two distinct hydrological seasons: the dry period (September to February) and the wet period (rainy season from March to August), when the water level can increase up to $15 \mathrm{~m}$. In the rainy season, rivers tend to flood, covering the forest and surrounding areas forming the so-called "igapós", which act as an important source of labile organic carbon to the water bodies, thus markedly affecting both the major nutrient cycles and mercury chemistry.

The mercury biogeochemical cycle in the Amazon is a topic of interest covered by several recent papers, ${ }^{4-16}$ but it is still poorly understood. High mercury concentrations have been found in soil (average value of $\left.170 \mu \mathrm{g} \mathrm{kg}^{-1}\right)^{4,5}$ and in other matrices ${ }^{5-12}$ in the Negro River basin. Different from other regions in the Amazon, this basin shows little gold-mining activity and there have been many indications that, in this region, naturally occurring mercury leaching from soil $(99.7 \%)$ is the major pathway to mercury enrichment. ${ }^{4}$ Podzolization can be pointed to as the major mechanism controlling the dynamics of $\mathrm{Hg}$ in soils and its release and transport to the aquatic system because constant rains and plains relief. ${ }^{5}$

In waters and sediments, mercury can be transformed into methylmercury under both biotic and abiotic conditions. ${ }^{17-22}$ Methylmercury concentrations in water rarely exceed $10 \%$ the mercury amount, while in sediments this value is lower, ${ }^{19,23-25}$ ranging from 0.1 to $2 \%$. Methylmercury is a species of particular interest because of its biomagnification in the food chain, its high toxicity, bioavailability and persistence in the environment. ${ }^{19,24}$

The biogeochemistry of mercury is complex, and its understanding demands a consistent study of other processes, such as chemical, atmospherical, geological, hydrological, microbial, physiological and ecological ones. This complexity has been recognized since the early studies on the occurrence of mercury in natural aquatic ecosystems, where high concentrations were found in fish despite the extremely low mercury concentration in water. ${ }^{5-16}$ Organic mercury concentrations in surface waters depend on the balance between methylation and demethylation and, therefore, show both spatial and temporal dependence. ${ }^{24}$ Generally the amount of methylmercury tends to increase in the presence of organic matter and to decrease as the concentration of the inorganic particulates increases. ${ }^{19,24}$

Sampling was undertaken as part of a broader project examining the mercury cycle in this basin, to evaluate possible sources and seasonal behavior of mercury species in the water column and sediments. Assessing methylmercury concentration and trends in aquatic bodies is important to understand the mercury cycle and to predict possible threats for both biota and humans. Besides, data related to the presence of organic mercury in the Negro River are still scarce. The major contribution of this study is to provide data on seasonal variations observed for both organic and total mercury obtained over three years of monitoring these species in this basin.

\section{Experimental}

\section{Sampling periods and stations}

The Negro River has an average flow of $29,000 \mathrm{~m}^{3} \mathrm{~s}^{-1}$ in Manaus where, after meeting the Solimões River, it forms the Amazon River. Rainfall in the Negro River basin varies from $3500 \mathrm{~mm}_{\text {year }}{ }^{-1}$ in the upper basin to 2137 $\mathrm{mm}$ year $^{-1}$ in the lower basin. The average temperature of the region varies from 24 to $33^{\circ} \mathrm{C}$.

Several surface water samples $(n=23)$ were collected in the Negro River basin (Figure 1) in January/2002 (dry season), January/2003 (dry season), June/2003 (rainy season) and January/2004 (dry season). Most samples (16 sampling points) were collected from black water bodies (BW1 to BW16), 5 samples were collected from white water bodies (WW1 to WW5) and two samples were collected in aquatic bodies with intermediate characteristics between black and white waters (IW1 and IW2). Table 1 presents a description of the sampling points with latitude and longitude references.

The behavior of mercury species in water has been evaluated through vertical profiles $(0,1$, and $3 \mathrm{~m}$ depth) in black water bodies. Moreover, waters from the Tarumã River were collected monthly during the period June 2003 to June 2004 to investigate the seasonal behavior of $\mathrm{Hg}_{\mathrm{ORG}}$, $\mathrm{Hg}_{\mathrm{R}}$ and $\mathrm{Hg}_{\mathrm{T}}$.

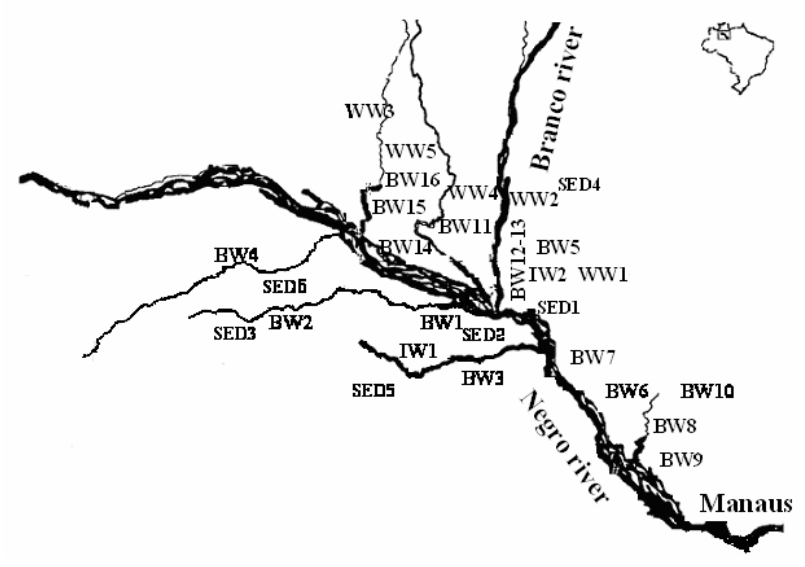

Figure 1. Map of the Negro River Basin region featuring the main rivers and sampling points. BW, WW and IW denote Black, White and Intermediate water samples, respectively; SED denote sediment samples. 
Table 1. Some selected physico-chemical parameters of water samples collected from different regions of the Negro River Basin

\begin{tabular}{|c|c|c|c|c|c|}
\hline Sampling Places* & Latitude & Longitude & $\mathrm{pH}$ & $\begin{array}{c}\text { Dissolved } \\
\text { Oxygen/(mg L-1) }\end{array}$ & $\begin{array}{l}\mathrm{TOC} / \\
\left(\mathrm{mg} \mathrm{L}^{-1}\right)\end{array}$ \\
\hline Iara Lake (BW1) & $01^{\circ} 20^{\prime}$ & $62^{\circ} 04^{\prime}$ & 4.6 & 5.8 & 15.3 \\
\hline Unini River (BW2) & $01^{\circ} 40^{\prime}$ & $60^{\circ} 32^{\prime}$ & 5.1 & 5.1 & 18.2 \\
\hline Jaú River (BW3) & $01^{\circ} 54^{\prime}$ & $60^{\circ} 12^{\prime}$ & 4.7 & 5.3 & 11.1 \\
\hline Caurés River (BW4) & $01^{\circ} 79^{\prime}$ & $62^{\circ} 19^{\prime}$ & 5.0 & 5.9 & 11.8 \\
\hline Jualperi River (BW5) & $01^{\circ} 26^{\prime}$ & $61^{\circ} 36^{\prime}$ & 5.7 & 5.3 & 12.3 \\
\hline Julião Igarapé (BW6) & $01^{\circ} 60^{\prime}$ & $60^{\circ} 04^{\prime}$ & 4.9 & 5.9 & 10.9 \\
\hline Mudo Igarapé (BW7) & $01^{\circ} 58^{\prime}$ & $60^{\circ} 06^{\prime}$ & 4.7 & 5.9 & 10.3 \\
\hline Guede Lake (BW8) & $01^{\circ} 59^{\prime}$ & $60^{\circ} 05^{\prime}$ & 4.6 & 5.1 & 11.2 \\
\hline Tarumã River (BW9) & $01^{\circ} 54^{\prime}$ & $60^{\circ} 03^{\prime}$ & 4.4 & 5.8 & 14.6 \\
\hline Campina Igarapé (BW10) & $20^{\circ} 30^{\prime}$ & $60^{\circ} 00^{\prime}$ & 3.9 & 5.0 & 23.7 \\
\hline Ramada Lake (BW11) & $01^{\circ} 00^{\prime}$ & $62^{\circ} 45^{\prime}$ & 4.7 & 5.2 & 13.3 \\
\hline Igarapé-Point 1 (BW12) & $01^{\circ} 19^{\prime}$ & $61^{\circ} 75^{\prime}$ & 4.6 & 5.7 & 12.8 \\
\hline Igarapé-Point 2 (BW13) & $01^{\circ} 22^{\prime}$ & $61^{\circ} 75^{\prime}$ & 5.1 & 5.6 & 11.6 \\
\hline Igarapé-Point 3 (WW1) & $01^{\circ} 24^{\prime}$ & $61^{\circ} 75^{\prime}$ & 5.7 & 5.2 & 8.3 \\
\hline Nazaré Lake (BW14) & $00^{\circ} 58^{\prime}$ & $62^{\circ} 54^{\prime}$ & 4.4 & 5.7 & 20.9 \\
\hline Nazaré Lake canal (BW15) & $00^{\circ} 58^{\prime}$ & $62^{\circ} 54^{\prime}$ & 4.4 & 5.5 & 25.1 \\
\hline Interior Lake (BW16) & $00^{\circ} 46^{\prime}$ & $62^{\circ} 56^{\prime}$ & 4.7 & 0.0 & 31.2 \\
\hline Branco River (WW2) & $01^{\circ} 14^{\prime}$ & $61^{\circ} 50^{\prime}$ & 7.2 & 5.3 & 5.3 \\
\hline Demini River (WW3) & $00^{\circ} 46^{\prime}$ & $62^{\circ} 58^{\prime}$ & 6.8 & 6.5 & 8.9 \\
\hline Fernandola Lake (WW4) & $00^{\circ} 46^{\prime}$ & $62^{\circ} 56^{\prime}$ & 5.5 & 5.2 & 6.5 \\
\hline Barro Branco Igarapé (WW5) & $20^{\circ} 56^{\prime}$ & $60^{\circ} 58^{\prime}$ & 4.9 & 5.9 & 5.9 \\
\hline Arupiaú Igarapé (IW1) & $01^{\circ} 10^{\prime}$ & $61^{\circ} 50^{\prime}$ & 4.1 & 5.8 & 14.3 \\
\hline Araçá Lake (IW2) & $01^{\circ} 14^{\prime}$ & $61^{\circ} 50^{\prime}$ & 6.5 & 5.9 & 11.2 \\
\hline
\end{tabular}

*BW, IW and WW denote black, intermediate and white water bodies, respectively.

Sediment samples were collected using an Ekman dredge or a gravity cylindrical collector in different sampling places indicated by SED1 to SED6 in the Figure 1 (Araçá and Iara Lakes; Unini, Jualperi, Jaú and Caurés Rivers).

\section{Cleaning and sampling procedures}

Precautions were taken in order to avoid contamination during sampling. The labware were placed in a $\mathrm{HCl}$ :water $(1: 4 \mathrm{v} / \mathrm{v})$ bath for $48 \mathrm{~h}$ at $80{ }^{\circ} \mathrm{C}$ on a hot plate. ${ }^{25}$ For water collection, bottles of polyethylene terephthalate (PET) commercialized for mineral water were used following the recommended procedure of Fadini and Jardim..$^{26}$ These authors validated the use of PET bottles, compared with the traditional Teflon bottles for both sampling and storage of low concentrations of total and reactive mercury. The bottles were washed several times at the sampling site and filled $10 \mathrm{~cm}$ below the surface. For both total and reactive mercury analysis, water samples were collected and preserved according to the procedure above mentioned prior to be transported to the laboratory in Campinas, São Paulo State, Brazil. ${ }^{26}$ Water samples for organic mercury analysis were extracted using methylene choride and stored in a refrigerator for transportation. ${ }^{27}$

Triplicate samples for total, organic and reactive $\mathrm{Hg}$ in non-filtered water samples were collected at each sampling point and the coefficient of variation for the results of Total and Reactive $\mathrm{Hg}$ was bellow 5\%. Because organic mercury concentrations are much lower than the ones obtained for total and reactive mercury, a lower precision among triplicate samples was observed (15\%).

Sediment samples were homogenized, stored in plastic bags and placed in a freezer at $-5^{\circ} \mathrm{C}$ until reaching the laboratory where carbon, methyl and total mercury concentrations were determined.

\section{Reagents and standards}

Analytical high-purity grade reagents were used throughout. Ultrapure water was obtained from a MilliQ System (Millipore). Mercury (II) chloride (Merck) and methylmercury chloride (Spectra Pure) were used as standards. A stock solution (1000 $\left.\mathrm{ng} \mathrm{L}^{-1}\right)$ in ultrapure water of each individual mercury compound was prepared daily. Methylmercury solutions were protected against the light by storing in the dark at $4{ }^{\circ} \mathrm{C}$. $\mathrm{SnCl}_{2}$ (Nuclear) solution was made by dissolving the salt in $\mathrm{HCl}$ (Mallinckrodt) to obtain a $10 \%(\mathrm{v} / \mathrm{v})$ solution. All solutions were prepared using ultrapure water.

\section{Analytical procedures}

Reactive, total, and organic mercury present in nonfiltered waters were quantified using double-stage gold 
amalgamation followed by Cold Vapor Atomic Fluorescence Spectrometry (CVAFS from Brooks Rand ${ }^{\oplus}$ model 2). Total mercury in sediment samples was quantified using the CVAAS technique adapted to FIA as described elsewhere. ${ }^{28}$ The limit of detection was $0.1 \mu \mathrm{g}$ $\mathrm{L}^{-1}$ when using $600 \mu \mathrm{L}$ of sample at an analytical frequency of 60 samples $^{-1}$. Methylmercury present in sediment was quantified using a gas chromatograph equipped with an electron-capture detector (GC-ECD). ${ }^{29,30}$

\section{Water samples}

Reactive mercury $\left(\mathrm{Hg}_{\mathrm{R}}\right)$ is an operationally defined parameter that embraces all mercury species amenable to be reduced by stannous chloride. Aliquots of $100 \mathrm{~mL}$ of water samples were placed in a wash bottle provided with a four-way valve and received the addition of $2 \mathrm{~mL}$ of $10 \%$ $(\mathrm{m} / \mathrm{v})$ stannous chloride solution. The elemental $\mathrm{Hg}$ formed was stripped out of the solution with argon and trapped onto a gold column. The first column was connected to the analytical column in the CVAFS, and the mercury was transferred to the second column by heating. From the analytical column, mercury was again released by heating and measured. The detection limit of this method is $40 \mathrm{pg}$.

Total mercury $\left(\mathrm{Hg}_{\mathrm{T}}\right)$ represents the sum of all mercury species present in water samples. The procedure involves the oxidation of all mercury species to $\mathrm{Hg}^{2+}$ by $\mathrm{BrCl}$ oxidation. ${ }^{31}$ The excess of this compound was eliminated by adding $30 \%(\mathrm{~m} / \mathrm{v})$ hydroxylamine chloride. All mercuric species are then reduced to elemental mercury by adding a $10 \%(\mathrm{~m} / \mathrm{v})$ stannous chloride solution, and $\mathrm{Hg}_{\mathrm{T}}$ is quantified according to the procedure described for reactive mercury. The detection limit of this method is $60 \mathrm{pg}$.

$\mathrm{Hg}_{\mathrm{ORG}}$ represents the stock of all organic mercury species present in the water samples, with methylmercury being the predominant one. The procedure for extraction and quantification of $\mathrm{Hg}_{\mathrm{ORG}}$ from water samples is based on acidic extraction using $10 \%(\mathrm{~m} / \mathrm{v}) \mathrm{HCl}$ followed by step wise $\mathrm{CH}_{2} \mathrm{Cl}_{2}$ extraction and back-extraction into water as described by Bisinoti and co-authors. ${ }^{27}$ The method consists in taking a $300 \mathrm{~mL}$ aliquot of the sample in a $500 \mathrm{~mL}$ Teflon bottle, followed by the addition of $15 \mathrm{~mL}$ of a saturated $\mathrm{KCl}$ solution in $10.0 \%(\mathrm{~m} / \mathrm{v}) \mathrm{HCl}$ and $30 \mathrm{~mL}$ of methylene chloride (Mallinckrodt) previously saturated with ultrapure water. The sample is shaken for $12 \mathrm{~h}$ in an orbital shaker at $150 \mathrm{rpm}$. The organic phase (methylene chloride) is transferred to another Teflon bottle containing $100 \mathrm{~mL}$ of MilliQ water. In a hood, the sample was then heated to $45^{\circ} \mathrm{C}$ to speed up the evaporation of methylene chloride and then purged with $\mathrm{N}_{2}$ to remove the remaining methylene chloride at room temperature. The organic mercury remaining was transferred to a Teflon bottle containing ultrapure water and oxidized by adding bromine chloride, letting the reaction occur for $30 \mathrm{~min}$. The excess of the oxidizing agent was destroyed with $500 \mu \mathrm{L}$ of a $30 \%(\mathrm{~m} / \mathrm{v})$ hydroxylamine chloride solution. After 5 minutes, the organic mercury was quantified as already described for reactive mercury. The detection limit of this method is $160 \mathrm{pg}$.

The determinations of $\mathrm{Hg}_{\mathrm{ORG}}, \mathrm{Hg}_{\mathrm{R}}$, and, $\mathrm{Hg}_{\mathrm{T}}$ were carried out in triplicate. The accuracy of the analytical method has been checked through mercury recovery ranges (90 to $100 \%$ ).

\section{Sediment samples}

Total mercury concentrations were determined using the conventional CVAAS procedure after the reduction of inorganic mercury with $\mathrm{SnCl}_{2}$ in acidic medium. ${ }^{28}$ The method consists in taking 1-2 $\mathrm{g}$ of wet sediment sample in $10 \mathrm{~mL}$ of MilliQ water, followed by the addition of 5 $\mathrm{mL}$ of concentrated sulfuric acid, $2.5 \mathrm{~mL}$ of concentrated nitric acid and $15 \mathrm{~mL}$ of $7 \%(\mathrm{~m} / \mathrm{v})$ potassium permanganate solution. After $15 \mathrm{~min}, 10 \mathrm{~mL}$ of $8 \%(\mathrm{~m} / \mathrm{v})$ potassium persulfate solution was added and the sample was heated at $80{ }^{\circ} \mathrm{C}$ for $2 \mathrm{~h}$. After cooling, the excess of permanganate was eliminated by adding $6 \mathrm{~mL}$ of $15 \%$ $(\mathrm{m} / \mathrm{v})$ hydroxylamine hydrochloride solution, and the final volume was adjusted to $50 \mathrm{~mL}$ with ultrapure water.

Mercury standard solutions and blanks used in the calibration procedure were prepared following this same procedure. ${ }^{4,27}$ Sediment samples were analyzed on a wet basis to avoid artifacts and losses associated with drying. A separate aliquot was analysed for percent humidity, in order to establish the appropriate correction for dry-basis measurements.

Methylmercury in sediment samples was determined by digesting samples in an alcoholic potassium hydroxide solution followed by a dithizone-toluene extraction. After a series of clean-up steps, methylmercury dithizonate was identified and quantified using the Akagi and Nishimura method ${ }^{29}$ which consists in the quantification of mercury present in the toluene layer using a gas chromatograph, Shimadzu model GC-14 B equipped with an electroncapture detector (ECD). Analytical quality control was based on the analysis of certified reference material (BCR580) for total and methylmercury in sediment. ${ }^{30}$

\section{Other physical and chemical parameters}

Analysis of the water samples included the determination of other parameters such as $\mathrm{pH}$, redox potential, temperature, conductivity and dissolved oxygen (DO) using a 
multiparameter equipment (ATI-ORION - PerpHect 370). ${ }^{32}$ TOC was measured using a Shimadzu TOC 5000 via the catalytic oxidation process (HTCO). Determination of organic carbon in sediments was carried out by means of an Elemental Analyzer (Perkin Elmer, 2004).

\section{Results and Discussion}

\section{Water samples}

According to Sioli, ${ }^{2}$ black water tributaries, as described before, are characterized by low concentrations of both nutrients and suspended sediments and by dark coloured waters due to a high content of humic compounds, leading to a water with low $\mathrm{pH}$. White water tributaries present higher concentrations of major elements, a close to neutral $\mathrm{pH}$, lower concentrations of DOC, and a high suspended sediment burden coming from the Andean mountains. In this work (Table 1) the black waters were characterized by high organic carbon contents (10.3-31.2 $\mathrm{mg} \mathrm{C} \mathrm{L}^{-1}$ ), low pH (3.9-5.7), temperatures typical of tropical waters $\left(29-33^{\circ} \mathrm{C}\right)$, Dissolved Oxygen (DO) of 0.0-5.9 mg L-1 and $\mathrm{E}_{\mathrm{H}}$ of 100-300 mV. In comparison, white water bodies showed low organic carbon (5.3-8.9 $\mathrm{mg} \mathrm{C} \mathrm{L} \mathrm{L}^{-1}$ ), neutral to slightly acidic $\mathrm{pH}$ (4.9-7.2), similar values for temperature $\left(29-33^{\circ} \mathrm{C}\right)$, higher DO (5.2-6.5 $\left.\mathrm{mg} \mathrm{L}^{-1}\right)$ and similar $\mathrm{E}_{\mathrm{H}}$ values $(100-300 \mathrm{mV})$. These results are in good agreement with previous data found in the literature, ${ }^{4-12}$ and are very important to explain the behavior of mercury species in these two different aquatic systems. Some selected physico-chemical parameters of water samples are presented in Table 1.

Total, reactive and organic mercury were measured in non-filtered surface water samples as previous attempts in working with filtered water samples showed consistent events of mercury cross-contamination. The results for total mercury ranged from $<0.3$ to $29.1 \mathrm{ng} \mathrm{L^{-1 }}$, and the concentration found for the other species are presented in Table 2. In Brazil, there are no guidelines for methylmercury in natural waters. Rudd ${ }^{18}$ has suggested that a concentration $\leq 0.1 \mathrm{ng} \mathrm{L} \mathrm{L}^{-1}$ of methylmercury should be representative of pristine waters although, in this case this background value cannot be used as the region is characterized by high concentrations of naturally occurring mercury ${ }^{4,5}$.

Major results obtained during all excursions (January/ 2002, January/2003, June/2003 and January/2004) showed detectable amounts of organic mercury in both white and black waters, with values oscillating from $<0.1 \%$ to $17.0 \%$ of the total mercury present for the black waters. For white waters, organic mercury content ranged from $<0.3 \%$ to $6.0 \%$ (Table 2). As pointed out by Fadini and Jardim, ${ }^{4}$ total mercury concentrations are higher in black waters when compared to those observed in white water bodies, which can be explained by the metal leaching from the soil caused by the acid $\mathrm{pH}$ and high organic content of black waters, as mentioned above.

Table 2. Average concentrations $(n=3)$ of the mercury species $\left(n g L^{-1}\right)$ in waters from the Negro River Basin

\begin{tabular}{|c|c|c|c|c|}
\hline Sampling place & $\mathrm{Hg}_{\mathrm{T}}$ & $\mathrm{Hg}_{\mathrm{R}}$ & $\mathrm{Hg}_{\mathrm{ORG}}$ & $\% \mathrm{Hg}_{\mathrm{ORG}}$ \\
\hline Iara Lake (BW1) & $10.3 \pm 0.02$ & $2.3 \pm 0.1$ & $1.20 \pm 0.03$ & 11.0 \\
\hline Unini River (BW2) & $2.3 \pm 0.02$ & $<0.3$ & $0.15 \pm 0.02$ & 6.5 \\
\hline Jaú River (BW3) & $4.7 \pm 0.03$ & $<0.3$ & $0.12 \pm 0.01$ & 2.6 \\
\hline Caurés River (BW4) & $3.1 \pm 0.03$ & $<0.3$ & $0.17 \pm 0.02$ & 5.5 \\
\hline Jualperi River (BW5) & $2.3 \pm 0.02$ & $<0.3$ & $0.23 \pm 0.03$ & 10.0 \\
\hline Julião Igarapé (BW6) & $1.7 \pm 0.01$ & $0.4 \pm 0.1$ & $<0.01$ & $<0.4$ \\
\hline Mudo Igarapé (BW7) & $<0.3$ & $<0.3$ & $<0.01$ & $<3.3$ \\
\hline Guede Lake (BW8) & $1.8 \pm 0.01$ & $0.5 \pm 0.1$ & $<0.01$ & $<0.4$ \\
\hline Tarumã River (BW9) & $4.7 \pm 0.05$ & $<0.3$ & $0.04 \pm 0.01$ & 0.8 \\
\hline Campina Igarapé (BW10) & $4.2 \pm 0.01$ & $0.7 \pm 0.3$ & $<0.01$ & $<0.1$ \\
\hline Ramada Lake (BW11) & $16.1 \pm 0.5$ & $3.9 \pm 0.31$ & $0.42 \pm 0.01$ & 2.6 \\
\hline Igarapé-Point 1 (BW12) & $7.8 \pm 0.03$ & $1.3 \pm 0.1$ & $1.30 \pm 0.01$ & 17.0 \\
\hline Igarapé-Point 2 (BW13) & $6.6 \pm 0.04$ & $0.9 \pm 0.1$ & $0.90 \pm 0.03$ & 14.0 \\
\hline Igarapé-Point 3 (WW1) & $7.3 \pm 0.03$ & $0.8 \pm 0.2$ & $0.20 \pm 0.01$ & 3.0 \\
\hline Nazaré Lake (BW14) & $10.4 \pm 0.3$ & $1.2 \pm 0.06$ & $0.92 \pm 0.04$ & 8.8 \\
\hline Nazaré Lake canal (BW15) & $10.0 \pm 0.4$ & $0.5 \pm 0.03$ & $1.21 \pm 0.02$ & 12.1 \\
\hline Interior Lake (BW16) & $29.1 \pm 0.3$ & $0.8 \pm 0.12$ & $1.63 \pm 0.03$ & 5.6 \\
\hline Branco River (WW2) & $3.4 \pm 0.01$ & $<0.3$ & $0.07 \pm 0.01$ & 2.0 \\
\hline Demini River (WW3) & $8.1 \pm 0.6$ & $1.1 \pm 0.07$ & $0.49 \pm 0.01$ & 6.0 \\
\hline Fernandola Lake (WW4) & $8.8 \pm 0.4$ & $1.2 \pm 0.06$ & $0.41 \pm 0.07$ & 4.7 \\
\hline Barro Branco Igarapé (WW5) & $2.1 \pm 0.02$ & $<0.3$ & $<0.01$ & $<0.3$ \\
\hline Arupiaú Igarapé (IW1) & $2.9 \pm 0.03$ & $0.5 \pm 0.1$ & $<0.01$ & $<0.2$ \\
\hline Araçá Lake (IW2) & $5.9 \pm 0.3$ & $2.0 \pm 0.14$ & $0.13 \pm 0.01$ & 2.2 \\
\hline
\end{tabular}

${ }^{*} \mathrm{~B}, \mathrm{I}$ and $\mathrm{W}$ denote black, intermediate and white water bodies, respectively. 
According to Maurice-Bourgoin and co-authors, ${ }^{33}$ Amazonian black water bodies, including the Negro River show a very low turbidity ( $5 \mathrm{NTU}$ ) when compared to the one observed for the Solimões River (around 80 NTU). Despite the low concentration of suspended solids (5 mg $\mathrm{L}^{-1}$ ), the high concentration of organic matter in this material is responsible for the transport of $61 \%$ of the total mercury in the Negro River. Similar results concerrning the load of suspended solids in this basin was carried out by Moreira-Turcq et al. ${ }^{34}$

Total mercury concentrations can be also dependent on the hydrological conditions, here presented as average monthly water level (daily measure with the aid of a ruler). Unfortunatelly numerous efforts to perform water filtration in situ always resulted in mercury contamination, where the mass balance of dissolved plus particulate led to errors around $100 \%$. The lack of speciation, however, does not impair mercury fluxes estimates, as this parameter refers to the total amount of the metal. As shown in Figure 2, throughout the dry season, total mercury values are higher than the ones obtained in the rainy season. The highest concentrations of $\mathrm{Hg}_{\mathrm{T}}$ and $\mathrm{Hg}_{\mathrm{ORG}}$ have been observed at Interior Lake, which also presented high TOC $(31.2 \mathrm{mg}$ $\left.\mathrm{C} \mathrm{L}^{-1}\right)$, acidic $\mathrm{pH}(4.7)$ and anaerobic conditions $\left(\mathrm{E}_{\mathrm{H}}=0.0\right.$ $\mathrm{mV}$ ), conditions essential to mercury methylation.

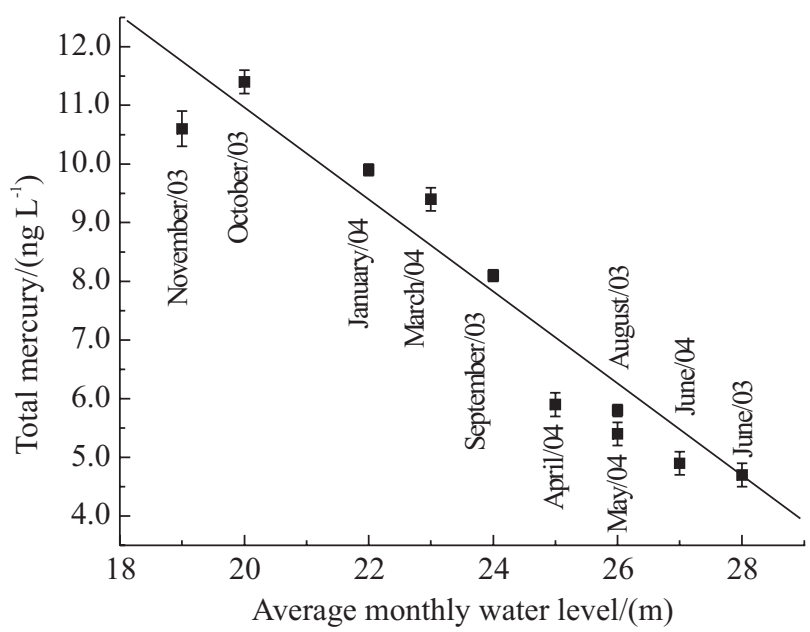

Figure 2. Dependence of the total mercury concentration on the average monthly water level in waters collected from the Tarumã River, close to Manaus.

In most natural water bodies, $\mathrm{Hg}_{\text {ORG }}$ concentrations do not show a correlation with the total mercury concentration. Methylmercury formation, from the toxicological point of view is considered the most important organic mercury species, is governed by a number of environmental factors, including temperature, $\mathrm{pH}$, redox potential, bacterial activity, inorganic and organic complexing agents, organic matter and inorganic mercury content. In a review ${ }^{17}$ dealing with the interaction of mercury and organic matter, it has been demonstrated that organic matter plays an important role in the bioavailability of mercury to methylating bacteria and subsequent bioaccumulation of methylmercury in the aquatic food chain.

Organic mercury concentrations ranged from $<0.01$ to $1.63 \mathrm{ng} \mathrm{L}^{-1}$, corresponding to $<0.1$ and $17 \%$ of the total mercury found in these waters. The highest $\mathrm{Hg}_{\text {ORG }}$ concentrations occurred in the Igarapé-Point 1, IgarapéPoint 2, Interior Lake, Nazaré Lake Canal, and Iara Lake, showing a different pattern from that observed for total mercury. High concentrations of organic mercury found in these points may be attributed to both high organic matter content and acidic conditions. Another aspect to possibly explain this behavior in flooded areas is due to the presence of sulfate reducing bacteria (SRB) and methanogenic bacteria, which can contribute to mercury methylation. ${ }^{24}$ Unfortunately, there have been few works focused on the Negro River basin exploring the real role of these bacteria in mercury methylation, thus demanding more detailed studies to better understand this mechanism. However, one important point to be highlited in this paper is the fact that the values obtained for $\mathrm{Hg}_{\mathrm{ORG}}$ are similar or even lower than the ones reported for freshwaters worldwide. ${ }^{35-47}$

Reactive mercury provides information on the availability of $\mathrm{Hg}$ for biogeochemical reactions. ${ }^{24}$ In general, the amount of $\mathrm{Hg}_{\mathrm{R}}$ in all sampled sites varied between about $24 \%$ and $8 \%$ of the total $\mathrm{Hg}$ for black and white waters, respectively, indicating that very little of the transported $\mathrm{Hg}$ in this basin is present as the free ion or labile species able to be reduced by stannous chloride. Poor correlations between total and reactive mercury concentrations $\left(\mathrm{R}^{2}=\right.$ $0.16)$ were observed in this study. The average results obtained in this work were compared with the results obtained in other areas of the Amazon Basin (Table 3) and were shown to be of the same order of magnitude.

For organic mercury (Figure 3) one can observe that, when the rainy season starts, there is an increase in the concentration of $\mathrm{Hg}_{\mathrm{ORG}}$ (from June through September) despite the increase in the water level. From this point on, as the water level increases, a concomitant decrease of organic mercury concentration is observed, due to the dilution effect. It is believed that, in this basin, during the early flooding periods organic mercury (or its precursors) is flushed from the newly flooded soil (igapós) into the aquatic system, thus increasing the concentration in the receiving waters.

Figure 4 shows the correlation between reactive and organic mercury species $(\mathrm{R}=0.9568)$, revealing that organic mercury production is higher when the supply of reactive 
Table 3. Concentrations $\left(\mathrm{ng} \mathrm{L}^{-1}\right)$ of different mercury species in waters from the Negro River Basin, compared to some selected water bodies in the Amazon Basin

\begin{tabular}{|c|c|c|c|c|c|}
\hline Sampling place & $\mathrm{Hg}_{\mathrm{R}}$ & $\mathrm{Hg}_{\mathrm{T}}$ & Methyl Hg & $\% \mathrm{Hg}_{\mathrm{ORG}}$ & Reference \\
\hline $\begin{array}{l}\text { Confluence Madeira } \\
\text { and Amazon River }\end{array}$ & - & 10.8 & - & - & 33 \\
\hline Madeira River & - & 7.0 & - & - & 33 \\
\hline Madeira River & - & 14.0 & - & - & 47 \\
\hline Madeira River & & 24.6 & & & 48 \\
\hline Tapajós & - & 2.8 & - & - & 49 \\
\hline Negro River & - & 4.5 & - & - & 50 \\
\hline Tapajós River & - & 1.1 & 0.24 & 22 & 51 \\
\hline Madeira River & - & 22.2 & - & - & 52 \\
\hline Amazon River & - & 11.3 & - & - & 52 \\
\hline Black waters, AM & 4.0 & 10.1 & $1.2^{*}$ & 12 & This work \\
\hline White waters, $\mathrm{AM}$ & 0.7 & 4.5 & $0.25^{*}$ & 5.6 & This work \\
\hline
\end{tabular}

"These values are for Organic Mercury and not for the methylmercury species only.

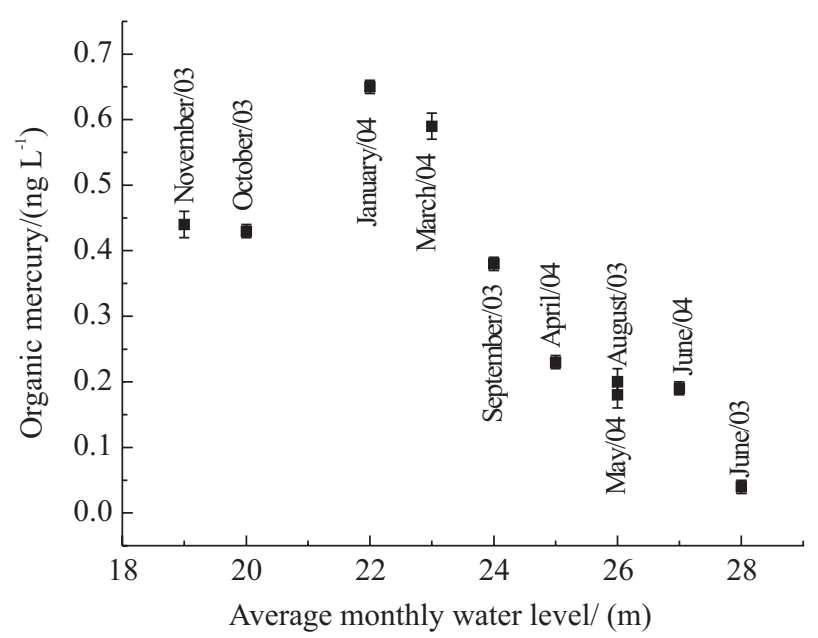

Figure 3. Dependence of the organic mercury concentration with the average monthly water level in waters collected from the Tarumã river, close to Manaus.

$\mathrm{Hg}$ is also high. This is another indication that, during rainy periods, inorganic mercury species and/or labile mercuryorganic matter complexes leached from the soil are carried to rivers and lakes in this watershed. Input of reactive mercury and labile organic matter into the water column during the flooding period has already been observed by Bisinoti et al..$^{53}$ In this work, the authors proposed the use of hydrogen peroxide consumption kinetics to infer organic matter lability in the water column and confirmed the input of this type of organic matter during flooding periods. ${ }^{53}$

The distribution of the mercury species in Ramada Lake (black waters) is shown in Figure 5. The species $\mathrm{Hg}_{\mathrm{T}}$ showed a constant vertical profile of concentration whereas, for $\mathrm{Hg}_{\mathrm{ORC}}$ and $\mathrm{Hg}_{\mathrm{R}}$, concentrations were slightly lower at surface compared to the deeper parts. This gradient is due to losses of the $\mathrm{Hg}_{\mathrm{ORG}}$, possibly due to photodegradation of this species in the upper layer of the photic zone as already mentioned in the literature, ${ }^{54}$ or due to the solar driven reduction of $\mathrm{Hg}^{2+}$ to

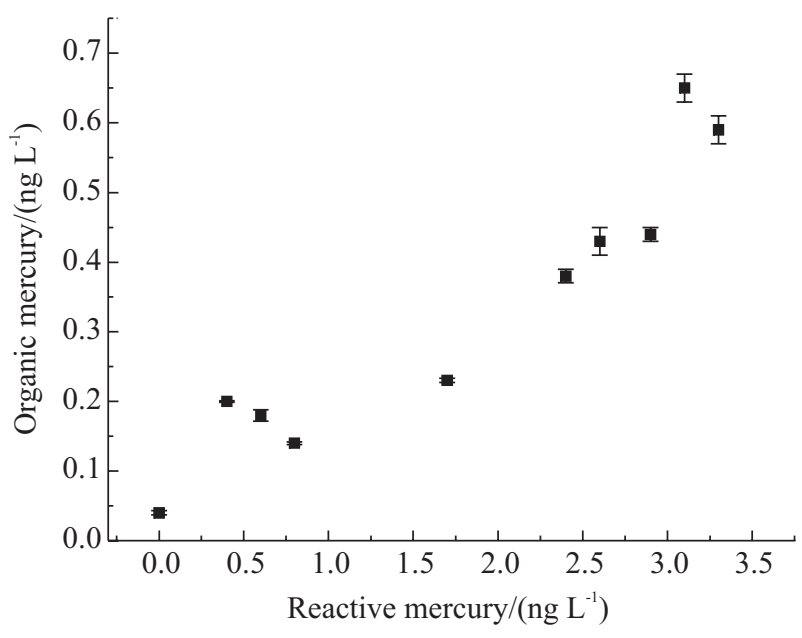

Figure 4. Correlation between organic and reactive mercury in waters collected from the Tarumã river, close to Manaus.

$\mathrm{Hg}^{0}$, thus lowering the concentration of the major substrate for the methylation process. A possible evasion of this species directly to the atmosphere cannot be excluded. According to Silva, ${ }^{12}$ the concentration of dissolved gaseous mercury in the Rio Negro is higher at the surface than at $3 \mathrm{~m}$ deeper, what causes an evasive water flux of elemental mercury under sunlight. Such behavior can be explained by assuming that solar radiation plays an important role in the destruction of methylmercury in the photic zone of these waters ${ }^{55}$. A similar trend has also been observed by Vandal et al. ${ }^{56}$

\section{Sediment samples}

Total and methylmercury concentrations obtained in sediment samples are shown in Table 4 and they are comparable to results found by other authors in other ecosystems throughout the world. ${ }^{57,58}$ Methylmercury concentrations in sediments ranged from 0.19 to $3.76 \mathrm{mg}$ 
Table 4. Total and methylmercury concentrations in sediment core samples from the Negro River Basin, Amazon

\begin{tabular}{|c|c|c|c|c|c|}
\hline Location (depth/cm) & CODE & Organic Carbon/(\%) & $\mathrm{Hg}_{\mathrm{T}} /\left(\mathrm{mg} \mathrm{kg}^{-1}\right)$ & $\begin{array}{l}\text { Methylmercury/ } \\
\quad\left(\mathrm{mg} \mathrm{kg}^{-1}\right)\end{array}$ & $\begin{array}{c}\text { Methylmercury/ } \\
(\%)\end{array}$ \\
\hline Araçá Lake (0-5) & & 4.3 & $155.4 \pm 9.0$ & $2.79 \pm 0.49$ & 1.79 \\
\hline Araçá Lake (5-10) & & 3.7 & $169.4 \pm 4.2$ & $2.11 \pm 0.17$ & 1.25 \\
\hline Araçá Lake (10-15) & SED1 & 2.7 & $119.4 \pm 5.3$ & $0.55 \pm 0.02$ & 0.46 \\
\hline Araçá Lake (15-20) & & 2.6 & $101.9 \pm 12.4$ & $0.52 \pm 0.02$ & 0.51 \\
\hline Araçá Lake (20-25) & & 2.6 & $88.0 \pm 6.3$ & $0.19 \pm 0.05$ & 0.22 \\
\hline Iara Lake $(0-5)$ & & 7.9 & $233.0 \pm 61.0$ & $3.76 \pm 0.24$ & 1.61 \\
\hline Iara Lake (5-10) & & 7.3 & $270.5 \pm 64.1$ & $3.35 \pm 0.46$ & 1.24 \\
\hline Iara Lake (10-15) & SED2 & 5.9 & $137.9 \pm 55.8$ & $1.47 \pm 0.09$ & 1.07 \\
\hline Iara Lake (15-20) & & 4.4 & $115.9 \pm 3.8$ & $1.11 \pm 0.07$ & 0.96 \\
\hline Iara Lake (20-25) & & 3.9 & $164.4 \pm 11.9$ & $0.41 \pm 0.12$ & 0.25 \\
\hline Unini River (0-5) & SED3 & 1.7 & $194.4 \pm 19.7$ & $2.23 \pm 0.21$ & 1.15 \\
\hline Jualperi River (0-5) & SED4 & 0.5 & $70.4 \pm 6.7$ & $0.33 \pm 0.06$ & 0.47 \\
\hline Jaú River (0-5) & SED5 & 1.3 & $169.6 \pm 18.0$ & $1.45 \pm 0.14$ & 0.86 \\
\hline Caurés River (0-5) & SED6 & 1.1 & $71.9 \pm 8.2$ & $0.65 \pm 0.06$ & 0.89 \\
\hline BCR-580* & - & 5.3 & $129000 \pm 4000$ & $69.3 \pm 7.5$ & 0.54 \\
\hline
\end{tabular}

"Certified values are $132000 \pm 3000$ and $75.5 \pm 3.7 \mathrm{mg} \mathrm{kg}^{-1}$ for total and methylmercury respectively in BCR-580.

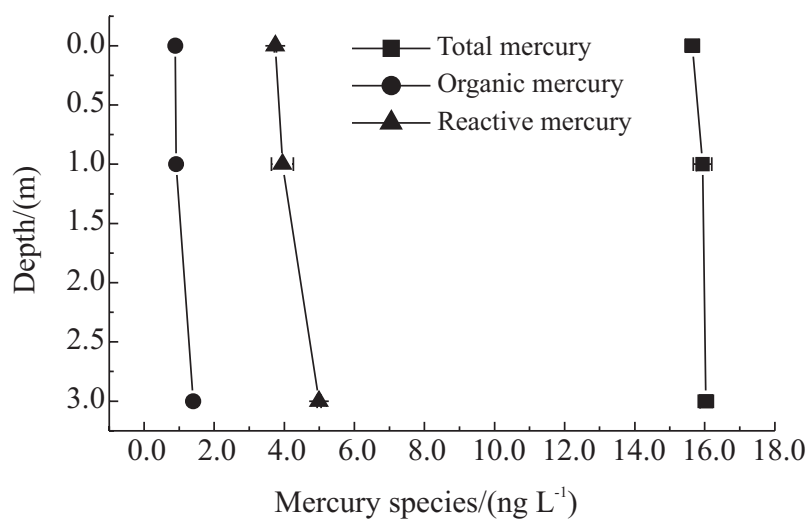

Figure 5. Vertical profiles for mercury species obtained in January/2004 at Ramada Lake at 2 PM.

$\mathrm{kg}^{-1}$, representing $0.22 \%$ to $1.79 \%$ of the total mercury (Table 4). The pattern of methylmercury in sediments is similar to that of $\mathrm{Hg}_{\mathrm{T}}$, again showing higher concentrations in sediment from black water lakes and rivers.

Sediment cores show a production of methylmercury in the upper layers $(0-10 \mathrm{~cm})$ and a gradual decrease with depth (Table 4) for Iara and Araçá Lakes, which could be explained by the higher organic carbon concentrations. Much higher concentrations were found in the Iara Lake sediment where more favorable conditions (acidic $\mathrm{pH}$ conditions and higher organic matter content) for the methylation of $\mathrm{Hg}$ occur.

\section{Conclusions}

Despite the pristine conditions of the Negro River watershed, the concentrations of total mercury found in surface waters are similar to those observed in industrialized areas, which can be explained by assuming high background concentrations of this metal due to natural occurrence. The singular conditions observed for black waters such as low $\mathrm{pH}$ and oxygenated water, as well as, the high organic matter content favour mercury methylation.

All the mercury species observed are determined by the local and unique hydrological conditions. Organic and reactive mercury concentrations increased in the beginning of the rainy season, mostly due to leaching from the soil. After this early period, due to the dilution effect, the concentration of all mercury species decreased. Total mercury correlated inversely with the average monthly rainfall for samples collected close to Manaus (Tarumã River). The major factors responsible for the high organic mercury content found in black waters are the input of soil containing labile, freshly produced organic matter, rich in humic acid observed in the early stages of the flooding periods, mediated by acidic $\mathrm{pH}$ conditions, and the possible presence of methanogenic bacteria in these waters.

\section{Acknowledgment}

The authors would like to thank Prof. C. H. Collins for revising the manuscript and the comments of the two reviewers. This work was supported by FAPESP (02/ 03395-1; 00/13517-1).

\section{References}

1. Instituto Brasileiro de Geografia e Estatística, Amazônia Brasileira. Geography Edition National Council of X Congresso Brasileiro de Geografia, Rio de Janeiro, September 1944, http:Ilwww.inep.gov.br (in Portuguese). 
2. Sioli, H.; Am. J. Trop. Med. Hyg. 1953, 2, 700.

3. Sioli, H.; Amazônia. Fundamentos da Ecologia da Maior Região de Florestas Tropicais, Editora Vozes: Petrópolis, 1985.

4. Fadini, P. S.; Jardim, W. F.; Sci. Total Environ. 2001, 275, 71.

5. Silva-Forsberg, M. C.; Forsberg, B. R.; Zeidemann, V. K.; Ambio 1999, 28, 519.

6. Malm, O.; Environ. Res. 1998, 77, 73.

7. Miretzky, P.; Bisinoti, M. C.; Jardim, W. F.; Rocha, J. C.; Quim. Nova 2005, 28, 438.

8. Rocha, J. C.; Sargentini Júnior, E.; Zara, L. F.; Rosa, A. H.; Santos, A.; Burba, P.; Talanta 2000, 53, 551.

9. Barbosa, A. C.; Jardim, W. F.; Dorea, J.G.; Forsberg, B. R.; Souza, J.; Arch. Environ. Contam. Toxicol. 2001, 40, 439.

10. Barbosa, A. C.; Souza, J.; Dorea, J.G.; Jardim, W. F.; Fadini, P. S.; Arch. Environ. Contam. Toxicol. 2003, 45, 235.

11. Fadini, P. S.; PhD Thesis, Universidade Estadual de Campinas, Brazil, 1999.

12. Silva, G. S.; PhD Thesis, Universidade Estadual de Campinas, Brazil, 2004.

13. Cordeiro, R. C.; Turcq, B.; Ribeiro, M. G.; Lacerda, L. D.; Sifeddine, A.; Turcq, P. F.M.; Sci. Total Environ. 2002, 293, 247.

14. Lechler, J. M.; Lacerda, L. D.; Lyons, W. B.; Bonzongo, J.; Sci. Total Environ. 2000, 260, 173.

15. Bastos, W. R.; Gomes, J. P. O.; Almeida, R.; Oliveira, R. C.; Nascimento, E. L.; Bernardi, J. V. E.; Lacerda, L. D.; Silveira, E. G.; Pfeiffer, W. C.; Sci. Total Environ. 2006, 368, 344.

16. Lacerda, L. D.; Riveiro, M. G.; Souza, M.; Environ. Pollution 2004, 129, 247.

17. Ravichandran, M.; Chemosphere 2004, 55, 319.

18. Rudd, J. W. M.; Water, Air, Soil Pollut. 1995, 80, 697.

19. Bisinoti, M. C.; Jardim, W. F.; Quim. Nova 2004, 27, 593.

20. Martian-Doimeadios, R. C. R.; Wasserman, J. C.; Bermejo, L. F. G.; Amouroux, D.; Nevado, J. J. B.; Donard, O. F. X.; J. Environ. Monitor. 2000, 2, 360.

21. Subramanian, V.; Madhavan, N.; Saxena, R.; Lundin, L. C.; J. Environ. Monitor. 2003, 5, 427.

22. Steffan, R. J.; Korthals, E. T.; Winfrey, M. R.; Appl. Environ. Microbiol. 1988, 54, 2003.

23. Villas-Bôas, R. C.; Beinhoff, C.; Da Silva, A. R.; Mercury in the Tapajos Basin, CNPQ/CYTED, CETEM: Rio de Janeiro, 2001.

24. Ullrich, S. M.; Tanton, T. W.; Abdrashitova, S. A.; Crit. Rev. Environ. Sci. Technol. 2001, 31, 241.

25. Bisinoti, M. C.; Jardim, W. F.; J. Braz. Chem. Soc. 2003, 14, 244.

26. Fadini, P. S.; Jardim, W. F.; Analyst 2000, 125, 549.

27. Bisinoti, M. C.; Júnior, J. L. B.; Malm, O.; Guimarães, J. R.; Jardim, W. F.; Quim. Nova 2006, 29, 1169.

28. Pasquini, C.; Jardim, W. F.; Faria, L. C.; J. Automat. Chem. 1988, 10, 188.
29. Akagi, H.; Nishimura, H.; Advances in Mercury Toxicology. Plenum Press: city ???, 1991, 53.

30. Kehrig, H. A.; Costa, M.; Moreira, I.; Olaf, O.; Mar. Pollut. Bull. 2002, 44, 1018.

31. Szakácss, O.; Lasztity, A.; Horváth, Z. S.; Anal. Chim. Acta 1980, 121, 219.

32. Clesceri, L. S.; Greenberg, A. E.; Eaton, A D.; Standard Methods for Examination of Water and Wastewater, $20^{\text {th }}$ edition, APHA: Washington, 1998.

33. Maurice-Bourgoin, L.; Quiroga, I.; Chincheros, J.; Courau, P.; Sci. Total Environ. 2000, 260, 73.

34. Moreira-Turcq, P.; Seyler, P.; Guyot, J. L.; Etcheber, H.; Hydrol. Processes 2003, 17, 1329.

35. Kannan, K.; Smith, R. G.; Lee, R. F; Windom, H. L.; Heitmuller, P. T.; Macauley, J. M.; Summers, J. K.; Arch. Environ. Contam. Toxicol. 1998, 34, 109.

36. Domagalski, J.; Appl. Geochem. 2001, 16, 1677.

37. Gill, G. A.; Bruland, K. W.; Environ. Sci. Technol. 1990, 24, 1392.

38. Gilmour, C. C.; Henry, E. A.; Environ. Pollut. 1991, 71, 131.

39. Bonotto, D. M.; Da Silveira, E. G.; J. South Am. Earth Sci. 2003, 15, 911.

40. Bloom, N. S.; Watras, C. J.; Sci. Total Environ. 1989, 87-8, 199.

41. Watras, C. J.; Morrison, K. A.; Host, J. S.; Bloom, N. S.; Limnol. Oceanogr. 1995, 40, 556.

42. Bloom, N. S.; Effler, S. W.; Water, Air, Soil Pollut. 1990, 53, 251.

43. Meuleman, C.; Leermakers, M.; Bayens, W.; Water, Air, Soil Pollut. 1995, 80, 539.

44. Parkman, H.; Ostlund, P.; Samulsson, M.; Iverfeldt, A.; Methylmercury in a Permanently Stratified Fjord. In: Watras, C.; Huckabee, J.; editors. Mercury pollution, integration and synthesis. Palo Alto, Lewis Publishers, 1995.

45. Nguyen, H. L.; Leermakers, M.; Kurunczi, S.; Bozo, L.; Baeyens, W.; Sci. Total Environ. 2005, 340, 231.

46. Bloom, N. S.; Effler, S. W.; Water, Air, Soil Pollut. 1990, 53, 251.

47. Lechler, P. J.; Miller, J. R.; Lacerda, L. D.; Vinson, D.; Bonzongo, J.-C.; Lyons, W. B.; Warwick, J. J.; Sci. Total Environ. 2000, 260, 87.

48. Nriagu, J. O.; Pfeiffer, W. C.; Malm, O.; Souza, C. M. M.; Mierle, G.; Nature 1992, 356, 389.

49. M. Roulet, M. Lucotte, R. Canuel, I. Rheault, S. Tran, Y. G. De Freitos Gog, N. Farella, R. Souza do Vale, C. J. Souza Passos, E. De Jesus da Silva, D. Mergler, M. Amorim, Sci. Total Environ. 1998, 213, 203.

50. Peleja, J. R. P.; PhD Thesis, Instituto Nacional de Pesquisa Amazônia, Brazil, 2002.

51. Roulet, M.; Lucotte, M.; Guimarães, J. R. D.; Rheault, I.; Sci. Total Environ. 2000, 261, 43. 
52. Bonotto, D. M.; Da Silveira, E. G.; J. Soc. Am. Earth Sci. 2003, $15,911$.

53. Bisinoti, M. C.; Fadini, P. S.; Jardim, W. F.; RMZ Materials and Geoenvironment 2004, 51, 821.

54. Sellers. P.; Kelly, C. A.; Rudd, J. W. M.; Machutchin, A. R.; Nature 1996, 380, 694.

55. Bisinoti, M. C.; Jardim, W. F.; RMZ Materials and Geoenvironment 2004, 51, 825.

56. Vandal, G. M.; Mason, R. P.; McKnight, D.; Fitzgerald, W.; Sci. Total Environ. 1998, 213, 229.
57. Watras, C. J.; Morrison, K. A.; Host, J. S.; Bloom, N. S.; Limnol. Ocean. 1995, 40, 556.

58. Nguyen, H. L.; Leermakers, M.; Kurunczi, S.; Bozo, L.; Baeyens, W.; Sci. Total Environ. 2005, 340, 231.

Received: July 9, 2006 Web Release Date: April 27, 2007

FAPESP helped in meeting the publication costs of this article. 